\title{
Ripening Regulation of Banana Cv. Malbhog Using Different Ripening Inducers
}

\author{
Ritambar Ghimire ${ }^{1, a}$, Pankaj Kumar Yadav ${ }^{1 b}$, Arjun Kumar Shrestha ${ }^{1, c}$, \\ Ananta Raj Devkota ${ }^{1, d}$, Shovit Khanal ${ }^{1, e}$ \\ ${ }^{1}$ Agriculture and Forestry University, Rampur, Chitwan, Nepal \\ *Corresponding author
}

A R T I C L E I N F O A B S T R A C T

Research Article

Received : 07/03/2021 Accepted : 31/08/2021
This experiment was carried out under the study entitled "Ripening regulation of the banana $\mathrm{Cv}$. Malbhog using different ripening inducers" for controlling the ripening of the banana, for improvement of quality attributes and post-harvest life of banana. The experiment was conducted at laboratory of horticulture, Agriculture and Forestry University, Rampur, Chitwan, Nepal from $14^{\text {th }}$ March to $16^{\text {th }}$ April 2019. These experiments were laid out in completely randomized design in which the first experiment comprised of seven treatments consisting of distilled water spray, ethephon@250 ppm, ethephon@500 ppm, ethephon@750 ppm, ethephon@1000 ppm, Dhurseli (Colebrookea oppositifolia) leaves and Ripe banana replicated thrice. Different post-harvest parameters were recorded at the interval of two days for the experiment till any one of the treatment attained score 6 in the color chart. In this experiment, the CI-6 stage was reached earlier on the $9^{\text {th }}$ day with the use of ethephon @ 1000 ppm but ethephon @ 500 ppm was found more effective regarding quality parameters with $\operatorname{TSS}\left(21^{\circ} \mathrm{B}\right)$, and TSS/TA (34.66). The maximum physiological loss in weight (12.927\%) and pulp peel ratio (3.65) was observed with ethephon@1000ppm and the minimum was achieved in banana sprayed with distilled water. The shelf life of banana was seen minimum (13.33 days) in ethephon@1000 ppm and maximum (20.33 days) in banana sprayed with distilled water.

\begin{tabular}{|c|c|}
\hline $\begin{array}{l}\text { Keywords: } \\
\text { Banana } \\
\text { Ethephon } \\
\text { Postharvest life } \\
\text { Ripening inducer } \\
\text { Quality }\end{array}$ & $\begin{array}{l}\text { attained score } 6 \text { in the color chart. In this experiment, the CI- } 6 \text { stage was reached earlier on the } 9^{\text {th }} \\
\text { day with the use of ethephon @ } 1000 \mathrm{ppm} \text { but ethephon @ } 500 \mathrm{ppm} \text { was found more effective } \\
\text { regarding quality parameters with TSS }\left(21^{\circ} \mathrm{B}\right) \text {, and TSS/TA }(34.66) \text {. The maximum physiological } \\
\text { loss in weight }(12.927 \%) \text { and pulp peel ratio }(3.65) \text { was observed with ethephon @ } 1000 \mathrm{ppm} \text { and the } \\
\text { minimum was achieved in banana sprayed with distilled water. The shelf life of banana was seen } \\
\text { minimum ( } 13.33 \text { days) in ethephon @ } 1000 \mathrm{ppm} \text { and maximum }(20.33 \text { days) in banana sprayed } \\
\text { with distilled water. }\end{array}$ \\
\hline
\end{tabular}

\section{Introduction}

Banana (Musa spp., family Musaceae) is a monocot, monocarpic and perennial plant grown in tropical and subtropical parts of the world (Shrestha, 2016). Nepal ranks $47^{\text {th }}$ in banana production (FAOSTAT, 2016). In Nepal, most commercial banana plantations are concentrated below $300 \mathrm{~m}$ in the Terai region (Ranjitkar et al., 2015). There are about 50 species in the Musaceae family with only two genera viz. Ensete and Musa. It is also regarded as a high-value crop of Nepal due to its large growing area, production, consumption and profit. So, commercial banana production is an important sector for uplifting the national economy of the country. Statistics show a significant increment in the area under production and productivity each year. Banana occupied an area of 17,839 hectares with a total productive area of 15,223 hectares and the production of 2, 47,622 Mt and productivity $16 \mathrm{Mt} / \mathrm{ha}$ in Nepal. Banana is the $4^{\text {th }}$ most important food crops in the world after rice, maize and wheat because of its rich and easily digestible carbohydrates with a caloric value of 67 to $137 / 100$ gram fruit (Arias et al., 2003). It is also a rich source of vitamins and minerals. Apart from its high nutritional value, delightful flavor and available in all seasons of the year; banana is a major source of macro elements, especially potassium and contain health beneficial ingredients such as resistant starch, total dietary fibers, rapidly digestible starch and slowly digestible starch. Banana have medicinal value too because of the presence of oligosaccharides: fructo oligosaccharide and polyphenols, catechin, epicatechin, epigallocatechin and gallic acid that has found applicable in the prevention of colon cancer, diabetes, muscular contraction, regulation of blood pressure and cure of intestinal disorder (Bantayehu, 2017). In Nepal, various improved varieties of banana have been introduced and tested in the field but Basrai Dwarf, Harichhal, William Hybrid, Malbhogetc showed the better result as compared to others. So, they are recommended for commercial cultivation in our context (Shrestha, 2010). A variety known as Jhapali Malbhog is also commercially grown in Jhapa, Morang, Sunsari, Chitwan and 
Nawalparasi district. Malbhog is one of the most common local cultivars which is superior in its quality, storability and taste and has got higher demand (Basnyat et al., 1996). Fruit pass through three development phases i.e. fruit set, fruit development and fruit ripening. Fruit ripening is the initiation of fruit senescence which is a genetically programmed highly coordinated process of organ transformation from unripe to the ripe stage to yield an attractive edible fruit. It is an irreversible phenomenon involving a series of biochemical, physiological, and organoleptic changes. These changes include changes in carbohydrate content, an increment of sugar content, changes in colour, texture, aroma volatiles, flavour compounds, phenolic compounds, and organic acids (Maduwanthi and Marapana, 2019). Banana being a climacteric fruit undergoes rapid ripening by an autocatalytic climacteric burst of gaseous hormone ethylene. Rapid textural change is followed by excessive tissue softening and subsequent spoilage of banana during late-ripen phase leads to heavy loss of the crop each year and its post-harvest losses range from 25-50\%. These losses occur during transportation and marketing due to adverse physiological changes, softening of flesh and lack of resistance capacity against microbial attack. Harvesting of banana at an appropriate stage of maturity, proper transport, post-harvest handling and storage are essential to delay ripening for the distant market. Non-availability of adequate post-harvest storage facilities and insufficient knowledge about storage has become a great threat to the commercial cultivation of banana. So, several techniques have been employed to delay fruit ripening and softening (Kader, 1994). This is possible through the use of certain chemical compounds like potassium permanganate and 1MCP which act against the exogenous or endogenous ethylene (Sahithya et al., 2017). Farmers are using their indigenous knowledge in the ripening banana since time immemorial. In many places, the bunch of banana after wrapping with a jute bag are hanged over the fire to meet the optimum desired temperature (Gautam and Dhakal, 1993). Smoke emits some ethylene gas which can trigger internal ethylene production in fruits (Adane et al., 2015). Along with smoking different material like Dhurseli leaves, Bakaina leaves, ripen banana and wounding are the other methods people practising in Nepal (Khatiwada, 2005; KCR et al., 2009). The most commonly used chemical for banana ripening are ethephon, ethylene glycol and calcium carbide (Islam et al., 2018). Calcium carbide is banned in different countries along with Nepal due to its toxic effect (Pokhrel, 2013). Ethephon simplest olefin ethylene is the gaseous plant hormone that regulates almost every aspect of plant growth and development. It is a simple two-carbon molecule that has capacity to provoke many responses like seed germination, fruit ripening, abscission, senescence etc by switching on or off hundreds of genes to affect a process (Lürssen, 2018). Ethylene produced by plant endogenously increases auto catalytically at a specific growth stage of plant to initiate physiological response whereas exogenous application of ethylene prior to autocatalytic production stage initiate physiological response and enhance endogenous ethylene production (Chaves and Mello-Farias, 2006). Different types of chemicals like ethanol, ethylene glycol, calcium carbide, mehyl jasmonate, methanol, ethrel and ethephon have been reported as ripening agent by different research groups (Goonatilake, 2008). Kaur (2017) reported that in Amrapali variety of Mango, 1000 ppm ethrel treatment showed superior result in terms of flavour, taste, color and marketability as compared to 500,750 and $1250 \mathrm{ppm}$ ethrel concentration. Similarly, the experiment conducted by different scientist in tomato reported that tomato ripening is accelerated by 2, 3 and 4 days by 500,750 and 1000 ppm ethephon concentration respectively as compared to control where quality attributes were better in $750 \mathrm{ppm}$ ethephon concentration (Moniruzzaman et al., 2015). Experiment conducted by Khatiwada (2005) in Chitwan reported that for uniform ripening and quality attributes of banana cultivar Malbhog, 1000-2000 ppm ethrel spray is optimum as compared to different calcium carbide concentration and other indigenous material. Mahajan et al. (2010) had observed the effect of 4 different concentration of ethephon (250 ppm, 500 ppm, 750 ppm and 1000 ppm) in Grand Naine banana. Mahajan et al. (2010) had observed the effect of 4 different concentration of ethephon (250 ppm, 500 ppm, 750 ppm and 1000 ppm) in Grand Naine banana. Indigenous plant materials like Moringa leaves, Asuro, Fresh rice straw, Dhurseli etc are also used as ripening agent for banana in some place of Nepal. They are used at about $10 \%$ of fruit but their efficiency was found less as compared to ethylene gas produced by artificial chemical compound (Khatiwada, 2005). Sogo-Temi, Idowu and Idowu (2014) reported that the biological ripening agents i.e. Irvingia gabonensis and Jatropha curcas showed higher protein content as compared to other chemical ripening agents i.e. Calcium carbide and Potash in the experiment done for comparing the nutrient composition in Banana. At the climacteric maximum, fruits like Mango, Tomato, Avocado, Pear and Banana produce 3, 35, 500, 40 and $40 \mu \mathrm{g} / 1$ ethylene (Belitz et al., 2006). Apple can rapid the ripening process similar as the synthetic ripening agents in banana with no chemical residue and safer for health (Singal et al., 2012). Ethylene produced by ripening climacteric fruits are more than sufficient to enhance ripening as an alternative to chemical compounds which can lead to negative impacts in health and environment (Pokhrel, 2013). Post-harvest study on ripening of banana was carried out at Regional Agriculture Research Station, Khajura to find out the effect 1000, 2000. 3000,4000 ppm ethephon concentration along with effect of indigenous material like Ashuro leaves (Adhatoda vesica), Koiralo leaves (Bahunia veriagata) and ripen banana. Those fruits treated with all ethephon concentration started to soften earlier in three days but with less shelf life of 8 days similar to the ripen banana experiment whereas 9 and 10 days shelf life was seen in koiralo and Ashuro leaves which takes 4 and 4.67 days to soften repectively which is far shorter than control i.e. 9 days (KCR et al., 2009). Thus, the fruits which are to ripen quickly and uniformly with better quality and should be marketed nearby should be treated with ethylene producing compounds that hasten de-greening and ripening in banana, while the fruits which have to be transported for long-distance markets should be treated with the chemicals that inhibit the ethylene synthesis in fruits. Considering the significance of the use of chemicals for the regulation of ripening as per the need of consumer and distance of market the investigatory work was conducted. To compare 
the effect of organic materials [Dhurseli leaves (Colebrookea oppositifolia) and ripe banana] and appropriate concentration of ethephon for banana ripening and its effect on quality attributes. To analyse the physicochemical changes in a banana during storage and ripening under different post-harvest treatment. The dose of chemicals to be applied depends on the variety, harvesting time, temperature as well as the relative humidity but the banana traders are unaware of the safe and the appropriate dose of the ethephon. So, people are facing problems related to the use of ethephon for the ripening of bananas. In the growing debate on the use of the ethephon for ripening, it is important for the use of appropriate dose and its consecutive effect on the ripening of banana.

\section{Materials and Method}

This experiment was conducted to study the postharvest quality of banana fruits.

Use of indigenous materials [Dhurseli leaves (Colebrookea oppositifolia) and ripe] and different concentration of ethephon to induce ripening of banana.

\section{Site Selection for Research Materials}

The banana bunches were brought from Amritnagar 22 $\mathrm{km}$ South from Narayangadh, Chitwan for the post-harvest treatment of banana. Geographically Amritnagar is located in the Terai belt at $27^{\circ} 60^{\prime} \mathrm{N}$ latitude and $84^{\circ} 31^{\prime}$ E longitude at an altitude of $607 \mathrm{ft}$ above sea level.

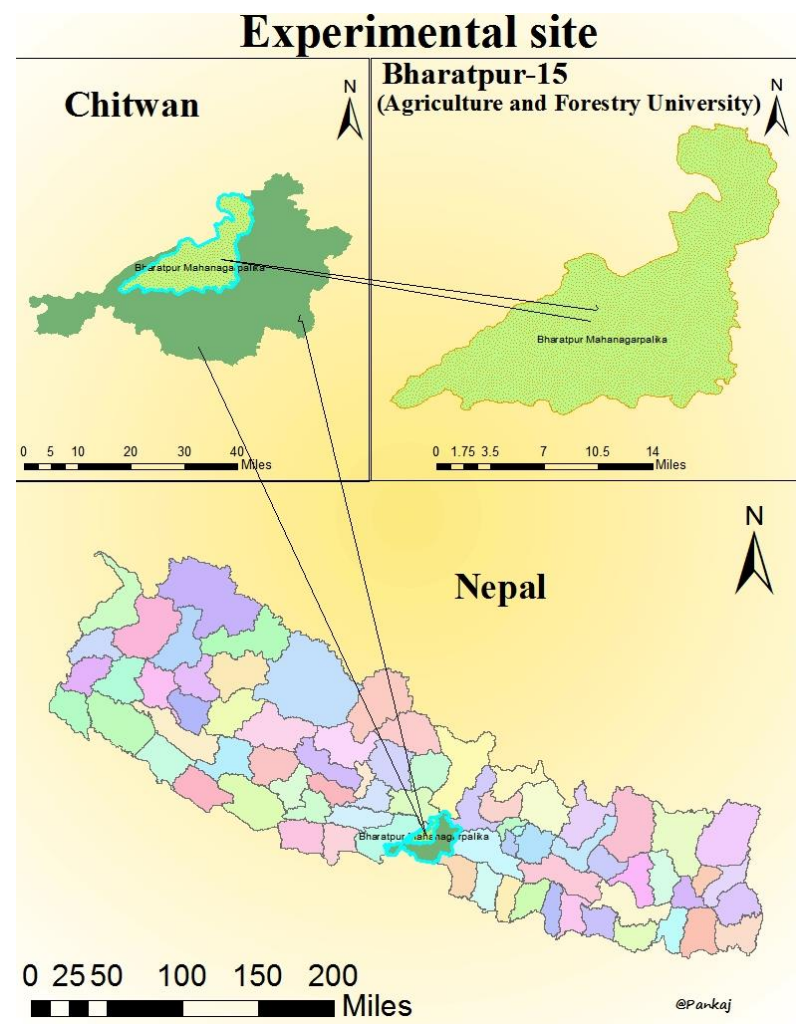

Figure 1: Map of Nepal showing experiment site

\section{Selection of The Cultivar}

The cultivar selected for the research is Malbhog which is one of the most popular and commonly cultivated variety in that locality. Malbhog is one of the Cavendish types of banana phenologically resembling to Harichhal and popularly grown in Nawalparasi, Chitwan, Jhapa, Morang and Sunsari districts (Gautam and Gautam, 2002).

\section{Location and Time of the Experiment}

The post-harvest analysis was carried out in horticulture laboratory, AFU, Rampur, Chitwan, Nepal. Geographically, Rampur is located in the Terai belt at $27^{\circ}$ $40^{\prime} \mathrm{N}$ latitude and $84^{\circ} 19^{\prime} \mathrm{E}$ longitude at an altitude of 228 masl. This place has a humid sub-tropical climate where summers are hot and winters are cold with total annual rainfall reported as $1582.6 \mathrm{~mm}$. This experiment was conducted from $14^{\text {th }}$ March to $16^{\text {th }}$ April.

\section{Harvesting of Banana and Selection of Fruits}

Uniform bunches of banana were selected and harvested with sharp knife. Then bunches were brought to Rampur and dehanded carefully. The individual fingers were separated from hand and washed with water. Then the individual fingers were dried in the shade overnight. The hand at the uppermost portion and lowermost portion of each bunch were discarded as they represent the extreme range of maturities and size in a bunch. The uniform fingers free from wound, cracks, insect damage and blemishes were selected. Twelve matured fingers were selected for each treatment.

\section{Design of Experiment}

The experiment was laid out in completely randomized design (CRD) with seven treatments and each treatment was replicated thrice.

$\mathrm{T} 1=$ Control, Spraying with distilled water,

$\mathrm{T} 2=$ SprayingwithEthephon @250 ppm,

T3 = SprayingwithEthephon @ 500 ppm,

T4 = SprayingwithEthephon @ 750 ppm,

T5 = Spraying with Ethephon @ 1000 ppm,

T6 $=$ Dhurseli leaves (5 leaves for 12 banana),

T7 = Ripe banana (2 banana for 12 banana),

Study done by Teeka Dahal (2019) also showed the use of Colebrookea oppositifolia shoot apex and leaves for banana ripening by Chhetri community in Tharu municipality of Parsa district. Khatiwada (2005) also revealed the effectiveness of dhurseli leaves in ripening of Malbhog banana. Colebrookea oppositifolia (part used: leaves). Its leaves were directly used to cover the banana (5 leaves were used for 12 banana).

Kripon was selected for fulfilling the required ethephon concentration. As kripon contain 39\% SL ethephon, required amount of kripon was diluted in distilled water to prepare $250 \mathrm{ppm}, 500 \mathrm{ppm}, 750 \mathrm{ppm}$ and $1000 \mathrm{ppm}$ solution.

Five fingers were kept for peel color rating. Peel color rating was done in all treatments at the initiation of treatment until ripening at every two days interval. To categorize the color in different index, peel color rating chart was used as described by (Acedo and Bautista, 1991) which is as follows:

$1=$ green, $2=$ pale green, $3=$ greenish yellow, $4=$ yellow green, $5=$ yellow with green tip $6=$ full yellow, 7 = yellow, lightly flecked with brown, $8=$ yellow with increasing brown areas.

Organoleptic taste in banana at CI-6 (full yellow) stage was carried out by groups of five people for flavour, astringency, sweetness and overall acceptability. Rating 
and Scoring was done by using five point rating scale technique (Miah, 1993). Banana of different treatment and replication were divided to 5 people and their experience or evaluations of sensory quality attributes were recorded.

Scale assigned for different parameters as follows:

\begin{tabular}{c|cccc}
\hline Scale & Sweetness & Astringency & Flavour & $\begin{array}{c}\text { Overall } \\
\text { acceptability }\end{array}$ \\
\hline 1 & Excellent & Excellent & $\begin{array}{c}\text { Very much } \\
\text { astringent }\end{array}$ & Excellent \\
0.8 & Good & Good & Astringent & Good \\
0.6 & Fair & Fair & Medium & Fair \\
0.4 & Poor & Poor & Less & Poorly \\
0.2 & Very poor & Very poor & No astringent & Unacceptable \\
\hline
\end{tabular}

Following laboratory reagents and treatment solutions were prepared for analysis and imposition of postharvest treatments. 4 gram of $\mathrm{NaOH}$ was dissolved in 1 litre of distilled water to prepare the solution of $0.1 \mathrm{~N} \mathrm{NaOH}$. Dye solution was made to determine the vitamin $\mathrm{C}$ content in the banana where $26 \mathrm{mg}$ dye (2,6- dichlorophenol indophenols) was mixed with $21 \mathrm{mg}$ sodium bicarbonate and they were dissolved in $100 \mathrm{ml}$ distilled water to prepare dye solution. At first $4 \mathrm{gm}$ of oxalic acid is dissolved in 100 $\mathrm{ml}$ distilled water and then $100 \mathrm{mg}$ of ascorbic acid is mixed in previous $4 \%$ oxalic acid solution to prepare stock standard solution. Previously prepared $10 \mathrm{ml}$ stock standard solution is taken and mixed with $4 \%$ oxalic acid solution to prepare working standard solution

A digital sensitive balance was used to determine fruit weight. The weight loss was calculated according to the formula:

$$
\mathrm{W}_{1}=\frac{\mathrm{W}_{0}-\mathrm{W}_{\mathrm{t}}}{\mathrm{W}_{0}} \times 100 \%
$$

Where $\mathrm{W}_{1}$ is the percentage weight loss, $\mathrm{W}_{0}$ is the initial fruits weight and $\mathrm{W}_{\mathrm{t}}$ is the weight of the fruits at the designated time.

During collection of data at every 2 days interval, Pulp and peel were separated with the help of sharp knife and weighed individually with the electronic digital balance at the time of TSS and TA determination and expressed as peel pulp ratio as

$$
\text { Pulp to peel ratio }=\frac{\text { Pulp weight }}{\text { Peel weight }}
$$

Shelflife of the fruits was measured in days from the initiation of the experiment up to $50 \%$ rotting.

Total soluble solids ( ${ }^{\circ}$ Brix) were determined with the help of hand held refractometer (Model: ERMA, Japan). One good fruit was randomly taken from each replication of all the treatments. After measuring weight of these sampled fruit, the peel was removed; flesh was grinded and sieved as well as squeezed in muslin cloth and juice was obtained. Two drops of homogenized juice was put on the prism of the refractometer and the reading was taken. Before recording the observation, calibration was done. These reading were averaged as per treatment and replications.

TA of the banana pulp was measured by using following formula;
Titratable acidity $(\%)=\frac{\mathrm{ml} \text { of } \mathrm{NaOH} \text { used } \times \text { Acid factor }}{\mathrm{ml} \text { of juice taken }} \times 100$

TSS/TA ratio was calculated by using by the formula,

$$
\frac{\text { TSS }}{\text { TA }}=\frac{\text { Total Soluble Solids }}{\text { Titratable Acidity }}
$$

The juice extracted by homogenizing the pulp in juice blender was previously squeezes and sieved in muslin cloth and collected in beaker. The $\mathrm{pH}$ meter was first calibrated using buffer solution and then the sensor electrode was dipped in the mixture contained in beaker. Then the digital $\mathrm{pH}$ meter showed data which was then recorded.

Due to great variation in observation parameters, 12 fingers were divided into two parts. Five non-destructive samples were numbered individually by stickers for observations like a storage life and peel color and physiological loss in weight, spoilage loss was calculated by weighing. Seven other fingers were selected as destructive samples for observations like TSS, TA, Pulppeel ratio at every 2 days interval.

Banana fingers were sprayed with respected concentration of plant growth regulator and then air dried for 10 minutes by keeping in air perforated plastic trays. In experiment ethephon of respected concentration were sprayed and for $7^{\text {th }}$ and $6^{\text {th }}$ treatment 2 Ripe banana and 5 Dhurseli leaves were kept respectively. Then each treatment was covered with transparent plastic by making some perforations for 48 hours. After $48 \mathrm{hrs}$, plastics were removed and observations were done.

\section{Results}

The results obtained from the laboratory experiment undertaken to assess the effectiveness of different postharvest treatments on the regulation of banana ripening, shelf life extension and quality performance are presented in this chapter with the help of tables and figures wherever necessary. The results were assessed and discussed with supporting evidence from previous works.

Experiment (Ripening Regulation of Banana with Ethephon, Dhurseli Leaves and Ripen Banana)

The mean value of data related to physiological loss in weight expressed in percentage under the influence of different post-harvest treatments (ethephon, dhurseli leaves and ripe banana) is displayed in Table1. The result showed the increment in physiological loss in weight with the advancement of storage period. All result showed significant variation during $3^{\text {rd }}, 6^{\text {th }}$ and $9^{\text {th }}$ days of observation. Ethephon $750 \mathrm{ppm}$ showed the highest PLW $(3.604 \%)$ which is significantly similar with Ethephon 1000 ppm (3.476\%) whereas other results were significantly lower with these two treatments. The lowest PLW (1.818\%) was recorded in untreated fruits which were significantly similar with dhurseli leaf treatment, ripe banana treatment and ethephon @ 250 ppm and ethephon @ 500 ppm. During the $6^{\text {th }}$ and $9^{\text {th }}$ day the highest PLW\% was recorded in ethephon@ 1000 ppm (7.563\% and $12.927 \%$ ) which were statistically at par with ethephon @ 750 ppm and ethephon @ 500 ppm on both $6^{\text {th }}$ and $9^{\text {th }}$ days. 
The result of the pulp to peel ratio of postharvest treated fruits and their mean values are presented in Table 2. During the ripening process, the weight of the fruit pulp increased that accompanied bya decrease in peel weight. There was no significant difference in the pulp to peel ratio on the $3^{\text {rd }}$ and $9^{\text {th }}$ day of the experiment whereas significant variation can be seen on $6^{\text {th }}$ day of the experiment. The highest pulp to peel ratio was depicted on bananas treated with ethephon@ 1000 ppm during the $3^{\text {rd }}, 6^{\text {th }}$ and $9^{\text {th }}$ days of storage with the value of 2.093, 2.49 and 3.65 respectively. All the treatments were statistically at par on the $6^{\text {th }}$ days of the experiment except control which showed the lowest value of $1.73,1.787$ and 2.863 during the $3^{\text {rd }}, 6^{\text {th }}$ and $9^{\text {th }}$ days of the experiment respectively. The results indicated that the pulp to peel ratio of banana fruits during ripening increased with the increase in the ethephon concentration and Dhurseli leaf and ripen banana as ripening inducers also showed equal effect as ethephon at low concentration i.e. $250 \mathrm{ppm}$ and $500 \mathrm{ppm}$.

There was a gradual increase in colour development of peel of both treated and untreated fruits as the banana approached full ripe condition as shown inTable 3 . The yellow color development in the peel of ethephon treated fruits and treatment with Dhurseli leaf and started after 3 days and increased faster during ripening as compared to control fruits indicating significant differences. All the result showed significant variation during the $3^{\text {rd }}, 6^{\text {th }}$ and $9^{\text {th }}$ days of the experiment for peel color change. The ethephon @ $1000 \mathrm{ppm}$ showed the maximum color value of 3, 5.33 and 6 which were statistically at par with Ethephon treated fruits@750 ppm at $3^{\text {rd }}, 6^{\text {th }}$ and $9^{\text {th }}$ days of the experiment whereas at $6^{\text {th }}$ and $9^{\text {th }}$ days it was significantly similar with $500 \mathrm{ppm}$ ethephon concentration. Dhurseli leaf and ripe banana also showed the positive result in ripening which have a lower value than different ethephon concentration but higher value than control.

The TSS is an important post-harvest quality parameter of banana fruits. The recorded data related to the TSS content of the banana is presented in Table 4. The TSS content of fruits increased during ripening irrespective of treatments. The result showed the significant difference during each day of data collection. All the treatments showed superior results as compared to the control. The highest TSS of $14.83,19$ and $20.33^{\circ}$ Brix was achieved in Ethephon@1000 ppm treated fruits at $3^{\text {rd }}, 6^{\text {th }}$ and $9^{\text {th }}$ days of the experiment respectively. The result from ethephon @ 1000 ppm was statistically at par with other ethephon concentration treated banana whereas Dhurseli leaf and ripen bananas treated fruits showed a significantly similar result with each other but significantly different with ethephon concentration in $9^{\text {th }}$ days of the experiment. The control showed the lowest result of 10, 12.33 and $15.33^{\circ}$ Brix on the $3^{\text {rd }}, 6^{\text {th }}$ and $9^{\text {th }}$ days of the experiment respectively.

Table1. Physiological loss in weight of banana under different post-harvest treatments during storage at ambient room temperature $\left(28 \pm 5^{\circ} \mathrm{C}\right)$, Rampur, Chitwan, 2019

\begin{tabular}{l|ccc}
\hline \multirow{2}{*}{ Treatment } & \multicolumn{3}{c}{ Physiological loss in weight (\%) } \\
\cline { 2 - 4 } & 3 DAS & 6 DAS & $9.417^{\mathrm{d}}$ \\
\hline Control & $1.818^{\mathrm{b}}$ & $3.652^{\mathrm{c}}$ & $9.207^{\mathrm{bcd}}$ \\
Ethephon @ 250 ppm & $2.319^{\mathrm{b}}$ & $5.078^{\mathrm{bc}}$ & $10.43^{\mathrm{abc}}$ \\
Ethephon @ 500 ppm & $2.351^{\mathrm{b}}$ & $6.128^{\mathrm{ab}}$ & $12.027^{\mathrm{ab}}$ \\
Ethephon @ 750 ppm & $3.604^{\mathrm{a}}$ & $6.139^{\mathrm{ab}}$ & $12.927^{\mathrm{a}}$ \\
Ethephon @ 1000 ppm & $3.476^{\mathrm{a}}$ & $7.563^{\mathrm{a}}$ & $8.51^{\mathrm{cd}}$ \\
Dhurseli leaves & $1.946^{\mathrm{b}}$ & $4.517^{\mathrm{bc}}$ & $8.133^{\mathrm{cd}}$ \\
Ripe banana & $2.196^{\mathrm{b}}$ & $4.647^{\mathrm{bc}}$ & 9.66 \\
Grand mean & 2.53 & 5.39 & $2.879^{* *}$ \\
LSD at 5\% & $0.846^{* *}$ & $1.561^{* *}$ & 1.342 \\
\hline SEm \pm ) & 0.39 & 0.73 & \\
\hline
\end{tabular}

Means within the same column followed by same letter do not differ significantly at $5 \%$ level by DMRT, *Note DAS=Days After Spraying, All digits in three significant.

Table 2. Pulp peel ratio of banana under different post-harvest treatments during storage at ambient room temperature $\left(28 \pm 5^{\circ} \mathrm{C}\right)$, Rampur, Chitwan, 2019

\begin{tabular}{l|ccc}
\hline \multirow{2}{*}{ Treatmemt } & & Pulp peel ratio & D DAS \\
\cline { 2 - 4 } & 3 DAS & 6 DAS & 2.683 \\
Control & 1.73 & $1.787^{\mathrm{b}}$ & 3.238 \\
Ethephon@ 250 ppm & 1.77 & $2.27^{\mathrm{a}}$ & 3.187 \\
Ethephon@ 500 ppm & 1.847 & $2.45^{\mathrm{a}}$ & 3.65 \\
Ethephon@ 750 ppm & 2.02 & $2.383^{\mathrm{a}}$ & 3.65 \\
Ethephon@ 1000 ppm & 2.093 & $2.49^{\mathrm{a}}$ & 2.657 \\
Dhurseli leaves & 1.8 & $2.077^{\mathrm{ab}}$ & 3.09 \\
Ripe banana & 1.92 & $2.25^{\mathrm{a}}$ & 3.17 \\
Grand mean & 1.883 & 2.244 & $\mathrm{NS}$ \\
LSD at 5\% & $\mathrm{NS}$ & $0.4048^{*}$ & 0.40 \\
\hline SEm $( \pm)$ & 0.204 & 0.189 & \\
\hline
\end{tabular}

Means within the same column followed by same letter do not differ significantly at $5 \%$ level by DMRT, *Note DAS=Days After Spraying, All digits in three significant. 
Table 3. Peel color rating of banana under different post-harvest treatments during storage at ambient room temperature $\left(28 \pm 5^{\circ} \mathrm{C}\right)$, Rampur, Chitwan, 2019

\begin{tabular}{|c|c|c|c|}
\hline \multirow{2}{*}{ Treatment } & \multicolumn{3}{|c|}{ Peel color rating } \\
\hline & 3 DAS & 6 DAS & 9 DAS \\
\hline Control & $1^{\mathrm{c}}$ & $2^{\mathrm{d}}$ & $3.333^{c}$ \\
\hline Ethephon@250 ppm & $2.667^{\mathrm{a}}$ & $4.333^{\mathrm{b}}$ & $5.333^{\mathrm{ab}}$ \\
\hline Ethephon@500ppm & $1.667^{\mathrm{bc}}$ & $4.667^{\mathrm{ab}}$ & $5.667^{\mathrm{a}}$ \\
\hline Ethephon@750 ppm & $2.333^{\mathrm{ab}}$ & $4.667^{\mathrm{ab}}$ & $5.667^{\mathrm{a}}$ \\
\hline Ethephon@1000 ppm & $3^{\mathrm{a}}$ & $5.333^{\mathrm{a}}$ & $6^{\mathrm{a}}$ \\
\hline Dhurseli leaves & $1.333^{\mathrm{c}}$ & $2^{\mathrm{d}}$ & $4.333^{\mathrm{bc}}$ \\
\hline Ripe banana & $1.333^{\mathrm{c}}$ & $3.333^{c}$ & $5^{\mathrm{ab}}$ \\
\hline Grand mean & 1.90 & 3.76 & 5.05 \\
\hline LSD at $5 \%$ & $0.855^{* * *}$ & $0.855^{* * *}$ & $1.081^{* *}$ \\
\hline $\operatorname{SEm}( \pm)$ & 0.398 & 0.398 & 0.504 \\
\hline
\end{tabular}

Means within the same column followed by same letter do not differ significantly at $5 \%$ level by DMRT, *Note DAS=Days After Spraying, All digits in three significant.

Table 4. TSS of banana under different post-harvest treatments during storage at ambient room temperature $\left(28 \pm 5^{\circ} \mathrm{C}\right)$, Rampur, Chitwan, 2019

\begin{tabular}{l|ccc}
\hline \multirow{2}{*}{ Treatment } & \multicolumn{3}{c}{ Total soluble solids ( ${ }^{\circ}$ Brix) } \\
\cline { 2 - 4 } & TSS 3 DAS & TSS 6 DAS & TSS 9 DAS \\
\hline Control & $10^{\mathrm{c}}$ & $12.33^{\mathrm{c}}$ & $15.33^{\mathrm{c}}$ \\
Ethephon @ 250 ppm & $13.67^{\mathrm{ab}}$ & $17.33^{\mathrm{ab}}$ & $20.33^{\mathrm{a}}$ \\
Ethephon @ 500 ppm & $12.67^{\mathrm{ab}}$ & $18.33^{\mathrm{a}}$ & $21^{\mathrm{a}}$ \\
Ethephon @ 750 ppm & $13.33^{\mathrm{ab}}$ & $17.33^{\mathrm{ab}}$ & $19.67^{\mathrm{a}}$ \\
Ethephon@ 1000 ppm & $14.83^{\mathrm{a}}$ & $19^{\mathrm{a}}$ & $20.33^{\mathrm{a}}$ \\
Dhurseli leaves & $11.5^{\mathrm{bc}}$ & $13^{\mathrm{c}}$ & $17^{\mathrm{b}}$ \\
Ripe banana & $11.67^{\mathrm{bc}}$ & $15.67^{\mathrm{b}}$ & $18^{\mathrm{b}}$ \\
Grand mean & 12.52 & 16.14 & 18.81 \\
LSD at 5\% & $2.162^{* *}$ & $1.709^{* * *}$ & $1.529^{* * *}$ \\
\hline SEm $( \pm)$ & 1.01 & 0.80 & 0.71 \\
\hline
\end{tabular}

Means within the same column followed by the same letter do not differ significantly at $5 \%$ level by DMRT, *Note DAS=Days After Spraying

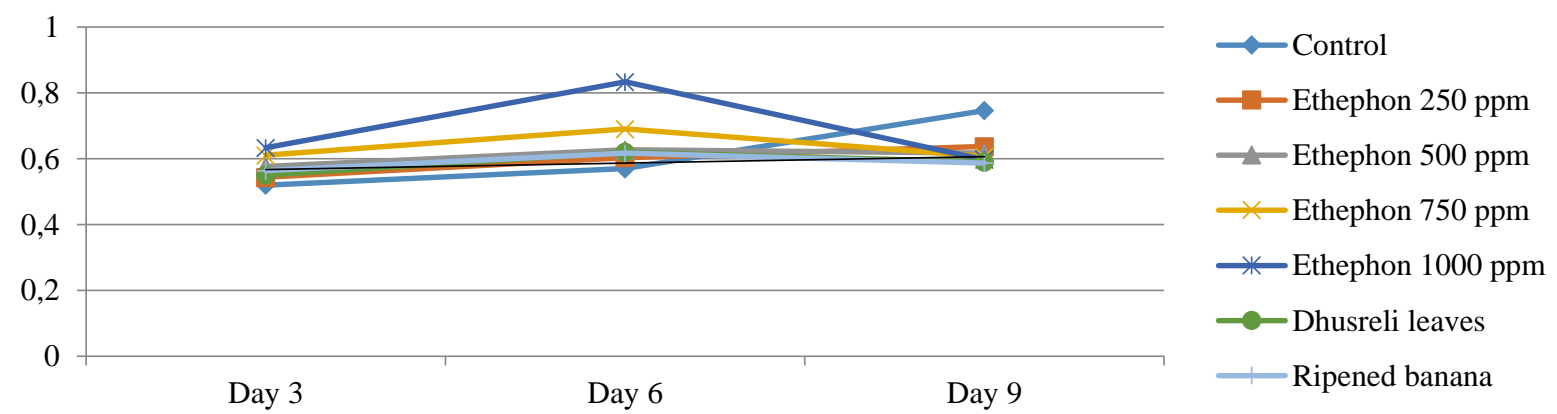

Figure 2. TA of banana fruit under different post-harvest treatments during storage at ambient room temperature $\left(28^{\circ} \mathrm{C}\right)$, Rampur, Chitwan, 2019

The titratable acidity of the banana finger during the experimental period under the influence of different postharvest treatments is presented in Table 5. The statistical analysis of data revealed that all the treatments under study resulted in a significant variation for the titratable acidity of the fruit. The general trend of alteration of acidity during ripening showed its continuous increment till ripening and then decrement at its post climacteric phase. On the $3^{\text {rd }}$ days of treatment the highest titratable acidity was achieved in $1000 \mathrm{ppm}$ ethephon treated fruits with the value of 0.633 which was statistically at par with ethephon@ 750 ppm and 500 ppm treated fruits. Dhurseli leaves and ripe banana showed slightly higher TA than control. A similar trend was seen on the $6^{\text {th }}$ days of treatment where TA in ethephon@1000 ppm treated fruits were significantly different from all the treatments. On the $9^{\text {th }}$ days of treatment highest titratable acidity was achieved in control with the value of 0.7467 which was significantly different fomother treatments. The lowest value was achieved in control during the $3^{\text {rd }}$ and $6^{\text {th }}$ days whereas on the $9^{\text {th }}$ day ripe banana treated fruits showed the lowest value.

The statistical analysis of data revealed that the $\mathrm{pH}$ of banana juice under different ripening inducing treatment showed significant variation at the $3^{\text {rd }}$ and $9^{\text {th }}$ days of treatment. 
Table 5. TA of banana under different post-harvest treatments during storage at ambient room temperature $\left(28 \pm 5^{\circ} \mathrm{C}\right)$, Rampur, Chitwan, 2019

\begin{tabular}{l|ccc}
\hline \multirow{2}{*}{ Treatment } & \multicolumn{3}{c}{ Titratable Acidity (\%) } \\
\cline { 2 - 3 } & 3 DAS & 6 DAS & 9 DAS \\
\hline Control & $0.52^{\mathrm{c}}$ & $0.57^{\mathrm{c}}$ & $0.7467^{\mathrm{a}}$ \\
Ethephon @ 250 ppm & $0.5433^{\mathrm{bc}}$ & $0.6033^{\mathrm{bc}}$ & $0.6367^{\mathrm{b}}$ \\
Ethephon @ 500 ppm & $0.5767^{\mathrm{abc}}$ & $0.6267^{\mathrm{bc}}$ & $0.6067^{\mathrm{b}}$ \\
Ethephon @ 750 ppm & $0.61^{\mathrm{ab}}$ & $0.69^{\mathrm{b}}$ & $0.5967^{\mathrm{b}}$ \\
Ethephon@ 1000 ppm & $0.6333^{\mathrm{a}}$ & $0.8333^{\mathrm{a}}$ & $0.59^{\mathrm{b}}$ \\
Dhurseli leaves & $0.55^{\mathrm{bc}}$ & $0.62^{\mathrm{bc}}$ & $0.5867^{\mathrm{b}}$ \\
Ripe banana & $0.5633^{\mathrm{bc}}$ & $0.6167^{\mathrm{bc}}$ & 0.6257 \\
Grand mean & 0.5710 & 0.651 & $0.07281^{* *}$ \\
LSD at 5\% & $0.06496^{*}$ & $0.0923^{* * *}$ & 0.3339 \\
\hline SEM & 0.0303 & 0.043 &
\end{tabular}

Means within the same column followed by the same letter do not differ significantly at 5\% level by DMRT *Note DAS=Days After Spraying

Table 6. $\mathrm{pH}$ of banana under different post-harvest treatments during storage at ambient room temperature $\left(28 \pm 5^{\circ} \mathrm{C}\right)$, Rampur, Chitwan, 2019

\begin{tabular}{l|ccc}
\hline \multirow{2}{*}{ Treatment } & & $\mathrm{pH}$ & 9 DAS \\
\cline { 2 - 4 } & $3 \mathrm{DAS}$ & $6 \mathrm{DAS}$ & $4.817^{\mathrm{a}}$ \\
\hline Control & $5.617^{\mathrm{a}}$ & 4.693 & $4.467^{\mathrm{b}}$ \\
Ethephon @ 250 ppm & $4.993^{\mathrm{bc}}$ & 4.38 & $4.573^{\mathrm{ab}}$ \\
Ethephon @ 500 ppm & $5.06^{\mathrm{bc}}$ & 4.323 & $4.533^{\mathrm{b}}$ \\
Ethephon @ 750 ppm & $4.937^{\mathrm{bc}}$ & 4.297 & $4.317^{\mathrm{b}}$ \\
Ethephon @ 1000 ppm & $4.567^{\mathrm{c}}$ & 4.173 & $4.8^{\mathrm{a}}$ \\
Dhurseli leaves & $5.27^{\mathrm{ab}}$ & 4.693 & $4.803^{\mathrm{a}}$ \\
Ripe banana & $5.307^{\mathrm{ab}}$ & 4.76 & 4.616 \\
Grand mean & 5.107 & 4.474 & $0.2397^{* *}$ \\
LSD at 5\% & $0.4820^{*}$ & $\mathrm{NS}$ & 0.1118 \\
SEM & 0.225 & 0.2204 & \\
\hline
\end{tabular}

Means within the same column followed by the same letter do not differ significantly at 5\% level by DMRT *Note DAS=Days After Spraying

Table 7. TSS/TA of banana under different post-harvest treatments during storage at ambient room temperature $\left(28 \pm 5^{\circ} \mathrm{C}\right)$, Rampur, Chitwan, 2019

\begin{tabular}{l|ccc}
\hline \multirow{2}{*}{ Treatment } & & TSS/TA & 9 DAS \\
\cline { 2 - 4 } & 3 DAS & 6 DAS & $26.16^{\mathrm{c}}$ \\
\hline Control & 19.27 & $21.71^{\mathrm{b}}$ & $34.47^{\mathrm{a}}$ \\
Ethephon @ 250 ppm & 25.17 & $28.8^{\mathrm{a}}$ & $34.66^{\mathrm{a}}$ \\
Ethephon @ 500 ppm & 21.94 & $29.29^{\mathrm{a}}$ & $30.9^{\mathrm{ab}}$ \\
Ethephon@ 750 ppm & 21.96 & $25.19^{\mathrm{ab}}$ & $27.52^{\mathrm{bc}}$ \\
Ethephon@ 1000 ppm & 23.41 & $23.12^{\mathrm{b}}$ & $27.57^{\mathrm{bc}}$ \\
Dhurseli leaves & 20.93 & $20.95^{\mathrm{b}}$ & $30.33^{\mathrm{abc}}$ \\
Ripe banana & 20.79 & $25.59^{\mathrm{ab}}$ & 30.23 \\
Grand mean & 21.92 & 24.95 & $4.065^{* *}$ \\
LSD at 5\% & $\mathrm{NS}$ & $4.605^{* *}$ & 1.90 \\
\hline SEM & 1.78 & 2.147 & \\
\hline
\end{tabular}

Means within the same column followed by the same letter do not differ significantly at 5\% level by DMRT *Note DAS=Days After Spraying

The lowest pH was achieved in ethephon @ 1000 ppm treated fruits with the value of 4.567 which was statistically at par with all other ethephon treated fruits. The highest $\mathrm{pH}$ was achieved in control with the value of 5.617 which was significantly similar to dhurseli leaves and ripe banana treated fruits. $\mathrm{pH}$ value was continuously decreased as the fruit gets ripen. On the $9^{\text {th }}$ days of treatment highest $\mathrm{pH}$ was achieved in control with the value of 4.817 which was significantly similar to the treatment of dhurseli leaves and ripe banana with the value of 4.8 and 4.803 and the lowest value of 4.317 was achieved in the treatment of ethephon @ 1000 ppm which was significantly similar with other ethephon treated fruits.
Statistical analysis of data revealed that TSS/TA ratio of banana juice showed significant variation only after the $6^{\text {th }}$ days of treatment. Data showed a continuous increment in TSS/TA ratio during the experiment. The highest ratio was achieved in $500 \mathrm{ppm}$ ethephon treated fruits at both $6^{\text {th }}$ and $9^{\text {th }}$ days with the value of 29.29 and 34.66 respectively which were significantly similar with ethephon $250 \mathrm{ppm}$, ethephon $750 \mathrm{ppm}$ and ripen banana treated fruits at both $6^{\text {th }}$ and $9^{\text {th }}$ days. The lowest value was achieved in control on the $9^{\text {th }}$ days of treatment which was statistically at par with Dhurseli leaves treated fruits and fruits treated with 1000 ppm ethephon. 
It is evident from the data in figure 2 that the storage shelf life of banana was significantly influenced by the different treatments. Naturally ripen banana showed a longer shelf life than the artificially ripen banana. The highest shelf life was observed at control with 20.33 days which was followed by the treatment with ripen banana with 18.33 days and it was significantly similar to the treatment of Dhurseli leaves. The lowest shelf life of 13.333 days was achieved in the treatment of ethephon @ 1000 ppm which was significantly similar to the treatment of ethephon@750 ppm and ethephon@500 ppm.

A group of five persons individually evaluated the sensory quality attributes of banana of different postharvest treatments for flavor, astringency, sweetness and overall acceptability at CI-6 stage of ripening. Significant differences were observed in terms of all quality attributes of banana. The respondents evaluated the untreated banana fruits and fruits ripe with dhurseli leaves and ripe banana to rank first in flavor. Ethephon @ 1000 ppm treated fruits ranked second and ethephon @ 250 ppm ranked third for flavor. Ethephon @ 1000 ppm treated banana fruits showed higher value for Astringency and ranked first whereas lower astringency is recorded in banana ripen by using ripe banana. Similarly, banana ripens by using ripe banana ranked first in terms of sweetness followed by control and dhurseli leaves treated banana. Similar Pattern is followed for Overall acceptability too where Ripen banana ranked first followed by control and Dhurseli leaves treated banana and the minimum value was observed in ethephon @ 1000 ppm treated fruits.

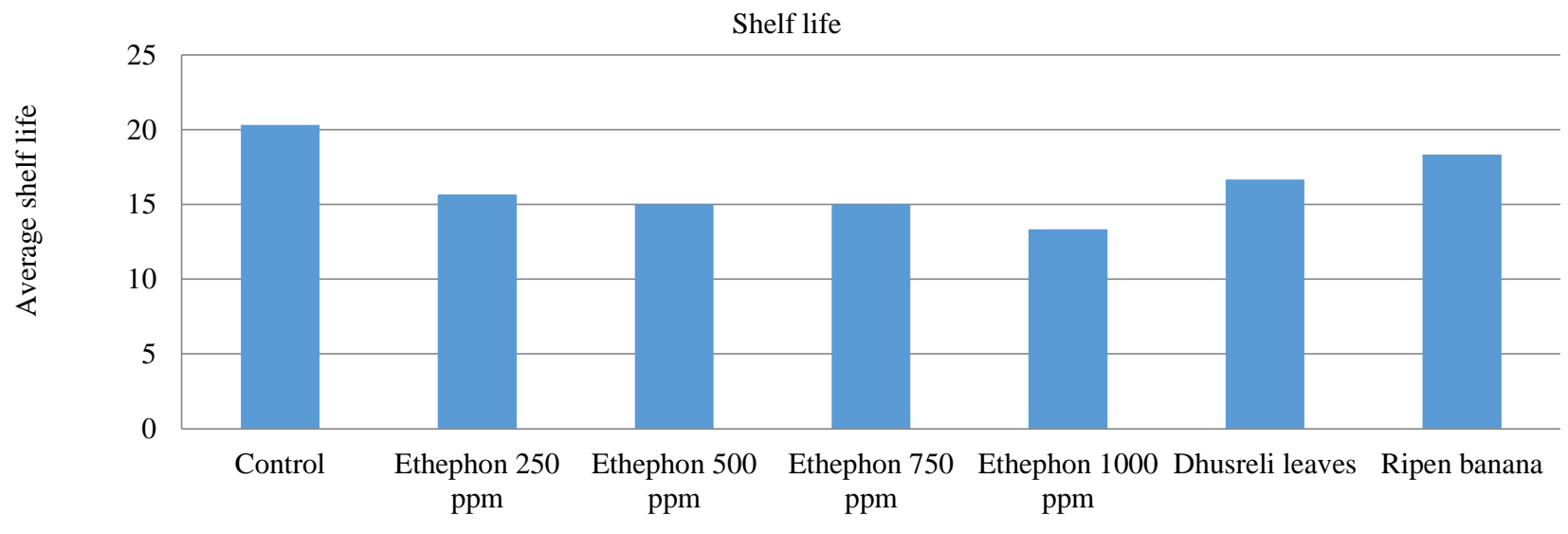

Figure 3. Shelf life of banana under different pos- harvest treatments during storage at ambient room temperature $\left(28^{\circ} \mathrm{C}\right)$, Rampur, Chitwan, 2019

Table 8. Acceptability of banana affected by organoleptic taste under different post-harvest treatments during storage at ambient room temperature $\left(28 \pm 5^{\circ} \mathrm{C}\right)$, Rampur, Chitwan, 2019

\begin{tabular}{|c|c|c|c|c|c|c|c|c|}
\hline Parameters & Rating & $\mathrm{T} 1$ & $\mathrm{~T} 2$ & $\overline{\mathrm{T} 3}$ & $\overline{\mathrm{T} 4}$ & $\overline{\mathrm{T} 5}$ & $\overline{\mathrm{T} 6}$ & $\overline{\mathrm{T} 7}$ \\
\hline \multirow{2}{*}{ Flavour } & IV & $0.92^{\mathrm{a}}$ & $0.64^{\mathrm{b}}$ & $0.6^{\mathrm{b}}$ & $0.68^{b}$ & $0.6^{\mathrm{b}}$ & $0.92^{\mathrm{a}}$ & $0.92^{\mathrm{a}}$ \\
\hline & $\mathrm{R}$ & I & III & IV & II & IV & I & I \\
\hline \multirow{2}{*}{ Astringency } & IV & $0.4^{\mathrm{cd}}$ & $0.64^{\mathrm{ab}}$ & $0.6^{\mathrm{ab}}$ & $0.64^{\mathrm{ab}}$ & $0.72^{\mathrm{a}}$ & $0.4^{\mathrm{cd}}$ & $0.28^{\mathrm{a}}$ \\
\hline & $\mathrm{R}$ & IV & II & III & II & I & IV & V \\
\hline \multirow{2}{*}{ Sweetness } & IV & $0.92^{\mathrm{a}}$ & $0.76^{b}$ & $0.68^{b}$ & $0.64^{\mathrm{b}}$ & $0.72^{b}$ & $0.92^{\mathrm{a}}$ & $0.96^{\mathrm{a}}$ \\
\hline & $\mathrm{R}$ & II & III & $\mathrm{V}$ & VI & IV & II & I \\
\hline \multirow{2}{*}{$\mathrm{OA}$} & IV & $0.88^{\mathrm{a}}$ & $0.68^{b}$ & $0.56^{b c}$ & $0.56^{\mathrm{bc}}$ & $0.48^{c}$ & $0.88^{\mathrm{a}}$ & $0.92^{\mathrm{a}}$ \\
\hline & $\mathrm{R}$ & II & III & IV & IV & V & II & I \\
\hline
\end{tabular}

IV: Index value, R: Rank, OA: Overall acceptability, Means within the same column followed by the same letter do not differ significantly at $5 \%$ level by DMRT

\section{Discussion}

\section{Physiological Loss in Weight (PLW\%)}

The highest PLW was observed with ethephon @ 1000 ppm which was significantly similar with Ethephon@750 ppm and the lowest with control fruits on $9^{\text {th }}$ DAS. A similar effect of ethephon in banana was observed by Gautam and Tiwari (2009) where the highest loss in weight was seen in 2000 ppm ethephon followed by 1000 ppm. The results obtained by Dhalland Singh (2013) in tomato are also in harmony with this finding. Present results are also in agreement with the findings of Kulkarni et al., (2011) where increment in PLW\% was directly proportional to the increment in ethrel concentration during the ripening process. They also concluded that this might be due to a rapid rise in respiration rate leading to faster ripening of the fruit than the untreated one. This is also similar to the Mahajan et al. (2010). According to Kaur (2017), Continuous processes of respiration, transpiration and surface evaporation through peel-tissue and other biological processes have resulted in weight loss. The less PLW\% in control might also be due to less respiration rate and other physiological process whereas the maximum loss was observed in ethrel @ 1000 ppm treated fruits (Pendharkar et al., 2011).

\section{Pulp to Peel ratio}

In the experiment, the highest pulp to peel ratio was observed with banana treated with ethephon@1000 ppm which was significantly similar with other ethephon concentration and the lowest was with control fruits on $6^{\text {th }}$ DAS where non-significant result was seen in $9^{\text {th }}$ DAS but 
the highest ratio was obtained at 1000 and $750 \mathrm{ppm}$ ethephon treated banana. This result is in harmony with the reports of Kulkarni et al. (2011) and also with Pendharkar et al. (2011). Ahmad et al. (2001) also reported that ethylene treated bananas showed greater pulp/peel ratios than untreated bananas. Mebrite et al. (2015) also reported the similar result where higher pulp peel ratio was obtained in ethephon treated and smoked banana.

According to Patil and Shanmugasundaram (2015) increase in pulp to peel ratio of banana is related to accumulation of moisture in the pulp derived from carbohydrate breakdown and osmotic transfer from peel to pulp which increase with increment in TSS of the pulp whereas peel further losses water to atmosphere from transpiration which is also in accordance with Newilah et al. (2009).

\section{Peel Colour Rating}

In this experiment, the highest colour score and lowest colour score was obtained with bananas treated with ethephon @ 1000ppm and control respectively on $9^{\text {th }}$ DAS. Similar result was obtained by KCR et al., in 2009 where ethephone treated and indigenous material treated one showed higher colour scale value than untreated one. Mebratie et al. (2015) also observed similar results where ethephone treated and smoked banana showed faster color change as compared to indigenous materials and control. Results of the present study are in agreement with the observations of Timilsina (2016) and Kulkarni et al., (2011). Subbaiah et al. (2013) also reported the similar result where they found the maximum score in $1000 \mathrm{ppm}$ ethrel treated banana after $6^{\text {th }}$ days of treatment and lowest at control. Breakdown of chlorophyll by ethylene might be the reason for faster color change in ethephon treated fruits. It is harmony with result concluded by Mahajan et al. (2008) and Mohamed and Abu- Goukh (2010) in guava. Color development induced by applied ethylene and ethylene releasing compounds has been demonstrated to be through reduction in chlorophyll concentration and increase in carotenoid pigments. According to Shrestha (2010), change in the peel color of banana is due to either the loss of chlorophyll or the synthesis of other pigments such as carotenoids and anthocyanins and the unmasking of these pigments formed earlier in banana.

\section{Total Soluble Solids}

In the experiment, the highest TSS was observed with ethephon@1000 ppm and the lowest TSS was with control fruits during $3^{\text {rd }}$ and $6^{\text {th }}$ days of observation and $500 \mathrm{ppm}$ ethephon treated fruits showed maximum TSS at $9^{\text {th }}$ DAS where TSS increase continuously during ripening process irrespective of treatments. Mahajanet al. (2010) also reported the highest TSS in banana fruits treated with 1000 ppm ethephon and lowest in untreated fruit. This result is in harmony with the observation of Subbaiah et al. (2014) where highest TSS was recorded in 1000 ppm ethrel treated fruits and lowest in control. In the experiment done by Kulkarniet al. (2010), highest TSS was observed in banana fruits treated by 500 ppm ethephon followed by 1000 ppm ethephon treated fruits after 6 days of storage. Abbas et al. (1994) also observed similar result in jujube where maximum TSS was recorded at 500 ppm ethephon treated fruits.
Mebrite et al. (2015) reported that increment in TSS of ethephon treated fruits might be due to exogenous ethylene source and less TSS in control might be due to absence of external ethylene source and reduced ethylene production. Increase in sugars during ripening could be attributed to hydrolysis of starch in to soluble sugars in the presence of ripening enzymes (Subbaiah et al., 2014). Tapre and Jain (2012) reported that increment in TSS during ripening might be due increase in concentration of organic solutes as a consequence of water loss and hydrolysis of starch into soluble sugars such as sucrose, glucose and fructose which is further supported by Adane et al. (2015).

Higher level of TSS in artificially ripen fruits was mainly due to faster change in peel color of such fruits. This could be due to the fact that in naturally ripen fruits, ripening get initiated from itself with consequent change in all parameters whereas in case of artificially ripening get initiated from outside to inside tissues i.e. from peel to pulp ripening (Khatiwada, 2005).

\section{Titratable Acidity}

In the experiment, the highest TA was obtained at 1000 ppm ethephon treated fruits during its peak ripening stage and minimum at control at $6^{\text {th }}$ DAS. The result showed continous increment in TA till peak ripening and again starts to decline. Shrestha (2010) observed decrease in acidity during ripening process of banana. Timilsina (2016) is in harmony with this result where maximum TA was obtained in 1000 ppm ethephon treated banana fruits. This result is also in agreement with report of Subbaiah et al. (2014) where Titratable acidity increased in all the treatments reaching a peak and decline later and quick decline were seen in higher concentration of ethephon treated fruits. Mahajan (2010) is also in accordance with above findings. According to Subbaiah et al. (2014) increment in acidity during ripening of banana might be due to obstruction in protein transfer as the fruit ripen and further decrease in acidity might be due to the utilization of organic acid in respiratory process. Kulkarni et al. (2010) also reported the same trend in alternation of Titratable acidity. Organic acid assimilation from respiration and rapid oxidation to carbonic acids and water might be the two major factors causing the increment in TA during ripening upto the climacteric peak (Pathak and Sanwal, 1999).

\section{Juice pH}

In this experiment the lowest pulp $\mathrm{pH}$ was measured in untreated fruits where maximum $\mathrm{pH}$ was observed at 1000 ppm ethephon treated fruits. $\mathrm{pH}$ declines continuously upto climacteric peak regardless of treatment this might be due to the increment in TA. This result is in accordance with Timilsina (2016) in banana where lowest $\mathrm{pH}$ was observed in $1000 \mathrm{ppm}$ ethephon treated fruits. Similar result was obtained by Kulkarni et al. (2010) where highest pH was obtained in untreated fruits and lowest in ethrel treated fruits. The inverse relationship of $\mathrm{pH}$ and Titratable acidity could be the reason behind decrease in $\mathrm{pH}$ of ethrel treated fruit during ripening (Kulkarni et al., 2010). The result is in harmony with Newilah et al. (2009) where value of $\mathrm{pH}$ decrease during ripening process and this might be due to the high production of malic acid during ripening. 


\section{TSS/TA Ratio}

In this experiment minimum TSS/TA ratio was obtained in control while highest result was recorded at 500 ppm ethephon treated fruits at $9^{\text {th }}$ DAS. Irrespective of the treatments the ratio showed continuous increment during ripening process. Similar result was obtained by Timilsina (2016) and Shrestha (2010). Increase in TSS/TA ratio might be due to the increment in TSS during early phase of ripening and decrease in TA after climacteric peak. Khatiwada (2005) stated that increase in TA during early stage of ripening results in decrease of TSS/TA ratio but higher degradation of the starch to sugar contributing increase in TSS results in increment of TSS/TA ratio at post climacteric phase.

\section{Shelf Life}

This experiment showed the maximum shelf life in control fruits and lowest in 1000 ppm ethephon treated fruits where Dhurseli leaves and ripen banana treated fruits showed higher shelf life than ethephon treated fruits. The result is in accordance with Shrestha (2016) and Khatiwada (2005). KCR et al. (2009) also recorded similar result where Asuro and ripen banana showed higher shelf life as compared to higher concentration of ethephon The report of Mahajan et al., (2010) is also in harmomy with this result where they concluded that the less shelf life in higher concentration of ethephon treated fruits was due to shattering of fingers from bunch, over-softening and shriveling of fruits. Longer shelf life in untreated banana might be due to less physio-chemical changes and slow ripening rate. Mebratie et al. (2015) stated that shorter shelf life in ethylene treated fruits might be due to accelerated physico-chemical changes.

\section{Organoleptic Taste}

This experiment showed higher rank in naturally ripen banana and banana treated with indigenous material for ripening. Timilsina (2016) and Khatiwada (2005) were also in harmony with this finding. Kulkarni (2011) was non contradictory with above findings where he observed excellent overall organoleptic characters in $500 \mathrm{ppm}$ and $1000 \mathrm{ppm}$ ethrel treated banana fruits as compared to untreated one in $6^{\text {th }}$ DAS which might be due to accelerated ripening in ethrel treated fruits and slower ripening in untreated one. Similarly, non contradictory result was observed by Mahajan et al. (2010) where he further concluded that the improvement in sensory quality with ethephon treatments may be due to role of ethephon in promoting changes quickly which are important to flavor quality and formation of aroma volatiles. Naturally ripen and Natural agents for ripening contributed higher sensory quality attributes in Banana as compare to other chemical agents (Gunasekara et al., 2015). Effect of ripen banana in banana ripening was also observed by KCR et al. (2009) where it showed higher sensory quality attributes.

\section{Conclusion}

The above results indicate that ethephon, Dhurseli leaves; ripen banana, caused significant effects on the physico-chemical parameters and shelf life of banana. Ethephon@1000 ppm performed better among other concentration of ethephon for physico-chemical properties and quick ripening while Dhurseli leaves and ripe banana showed less effect which might be due to less amount of ethylene release by these materials. During advancement of storage period banana continually loss water, TSS increase, TA increase till ripening peak but the process is higher in banana fruits treated with higher ethephon concentration.

\section{References}

Abbas MF, Al-Niami JH, Al-Sareh EA. 1994.The effect of ethephon on the ripening of fruits of jujube. Journal of Horticultural Science, 69(3): 465-466.

Ahmad S, Thompson AK, Hafiz IA, Asi AA. 2001. Effect of temperature on the ripening behavior and quality of banana fruit. Int. J. Agric. Biol, 3(2): 224-227.

Arias P, Dankers C, Liu P, Pilkauskas P. 2003. The world banana economy.Food and Agriculture Organization of the United Nations, Rome.

Bantayehu M. 2017. Fruit ripening and postharvest life of banana varieties at different temperatures and packaging. Journal of Postharvest Technology, 05(1): 30-42.

Basnyat RC, Shrestha GK, Dhital P, Thapa RB. 1996. Socioeconomic conditions of banana growers and their practices in banana production, handling and marketing in Chitwan district district: a case study, IAAS Research Reports (1994-1995), 27-35.

Belitz HD, Grosch W, Schierberle P. 2009. Food Chemistry. 4th revised and extended Edition. SpringerPublications. USA.

Biniam Mesfin G, Bower JP. 2017. Effect of GA3, Waxing and Micro Perforated bags on shelf life and selected quality attributes of papaya fruit. Journal of Postharvest Technology, 05(4): 10-24.

Chaves ALS, Mello-Farias PCD. 2006. Ethylene and fruit ripening: From illumination gas to control of gene expression, more than a century of discoveries. Genetics and Molecular Biology, 29, 3: 508-515

Dhall RK, Singh P. 2013. Effect of ethephon and ethylene gas on ripening and quality of tomato Solanum lycopersicum L. during cold storage. Journal of Nutrition \& Food Sciences, $3(6), 1$.

FAOSTAT. 2015. FAO database. In: Food Agric. Organ. United Nations.http://faostat3.fao.org/ download/Q/QC/E. Retrieved on $01 / 06 / 2019$.

FAOSTAT. 2017. UN Food and Agriculture Organization, Corporate Statistical Database. "Banana and Plantain Production in 2016, Crops/ Regions/ World list/ Production Quantity". Retrieved on 03/06/2019.

Goonatilake R. 2008. Effects of diluted ethylene glycol as a fruitripening agent. Global Journal of Biotechnology \& Biochemistry, 3(1): 8-13.

Gunasekara SRW, Hemmamali KKGU, Dayananda TG, Jayamanne VS. 2015. Post harvest quality analysis of embul banana following artificial ripening techniques, International Journal of Science, Environment, 4: 1625-1632.

ICIMOD. 2015. Expanding Commercial Banana Production. International Center for Integrated Mountain Development. Kathmandu, Nepal.

Jain MC, Choudhary HD, Sharma MK, Singh B. 2014. Yield and Quality Attributes of Nagpur Mandarin as Affected by Use of Different Plant Growth Regulators. Environment and Ecology, 32(3): 1141-1145.

KCR, Gautam D, Tiwari S. 2009. Use of Ethephone and Indigenous Plant Materials in Ripening Banana in Winter. Nepal Agric. Res. J.,9.

Kader AA. 1994. Regulation of fruit physiology by controlled/modified atmospheres. Postharvest Physiology of Fruits 398: 59-70. 
Kaur G, Saha S, Kumari K, Datta AK. 2017. Mango pulp drying by refractance window method. Agricultural Engineering International: CIGR Journal, 19(4).

Khatiwada BP. 2005. Ripening regulation of banana (Musa sapientum L.) cv. Malbhog using chemicals and indigenous plant materials.Msc thesis.Department of horticulture.Institute of Agriculture and Animal Science.Rampur, Chitwan, Nepal.

Lürssen K. 2018. Ethylene and agriculture. In The Plant Hormone Ethylene (pp. 315-326). CRC Press

Maduwanthi SDT, Marapana RAUJ. 2019. Effect of ethephon and acetylene treatments on chlorophylls and carotenoids pigments in banana (Musa acuminata, AAB). 4th International Research Symposium on Pure and Applied Sciences, Faculty of Science, University of Kelaniya, Sri Lanka.

Mahajan BVC, Singh G, Dhat AS. 2008. Studies on ripening behavior and quality of winter guava with ethylene gas and ethephon treatment.Journal of Food Science and Technology, 45(1): 81-84.

Manjunatha G, Guptha KJ, Lokesh V, Luis Aj Mur, Bhagyalakhmi N. 2012. Nitric oxide counters ethylene effects on ripening fruits. Plant Signalling Behaviour, 7, 476-483.

Martínez-Romero D, Valero D, Serrano M, Burló F, Carbonell A, Burgos L, Riquelme F. 2000. Exogenous polyamines and gibberellic acid effects on peach (Prunus persica L.) storability improvement. Journal of Food Science, 65(2), 288294.

Mebratie MA, Woldetsadik K, Ayalew A, Haji J. 2015. Comparative Study of Different Banana Ripening Methods. Science, Technology and Arts Research Journal, 4(2): 32-38.

Mohamed-Nour IA, Abu-Goukh AA. 2010. Effect of ethrel in aqueous solution and ethylene released from ethrel on guava fruit ripening. Agriculture and Biology Journal of North America, 1(3): 232-237.

Moniruzzaman M, Khatoon R, Hossain MFB, Rahman MT, Alam SN. 2015. Influence of ethephon on ripening and quality of winter tomato fruit harvested at different maturity stages. Bangladesh Journal of Agricultural Research, 40(4):567-580

Nelson SC, Ploetz RC, Kepler AK. 2006. Musa species (banana and plantain). Species Profiles for Pacific Island Agroforestry, 15(2): 251-259.

Newilah GN, Tomekpe BK, Fokou BE, Etoa BFX. 2009. Physicochemical changes during ripening of bananas grown in Cameroon. Fresh produce, 3(3), 1.
Patil SK, Shanmugasundaram S. 2015. Physicochemical changes during ripening of monthan banana. Int. J. Technol. Enhanc. Emerg. Eng. Res, 3, 18-21.

Pendharkar PY, Hiwale SS, Patil AB. 2011. Studies on the effect of ethrel on ripening of banana fruits cv. Grand naine. Asian Journal of Horticulture, 6(2), 309-312.

Pokhrel P. 2013. Use of Higher Ethylene Generating Fruits for Ripening as an Alternative to Ethylene. J. Food Sci. Technol. Nepal, 8:84-86.

Ram BKC, Gautam DM, Tiwari S. 2009. Use of Ethephone and Indigenous Plant Materials in Ripening Banana in Winter. Nepal Agriculture Research Journal, 9: 113-117.

Ranjitkar S, Sujakhu N, Budhamagar K, Rimal S, Xu J, Merz J, Zomer RJ. 2015. Projected climate change impacts on climatic suitability and geographical distribution of banana and coffee plantations in Nepal. World Agroforestry Center (ICRAF): Nairobi, Kenya.

Rossetto MRM. Purgatto E, do Nascimento JRO, Lajolo FM, Cordenunsi BR. 2003. Effects of gibberellic acid on sucrose accumulation and sucrose biosynthesizing enzymes activity during banana ripening. Plant Growth Regulation, 41(3): 207 214.

Shrestha BK. 2010. Effect of postharvest treatments on prolonging shelf life of banana. MSc Thesis. Department of Horticulture.Agriculture and Forestry University, Rampur, Chitwan, Nepal.

Singal S, Kumud M, Thakral S. 2012. Application of apple as ripening agent for banana.Indian Journal of Natural Products and Resources,03(01): 61-64.

Sogo-Temi CM, Idowu OA, Idowu E. 2014. Effect of biological and chemical ripening agents on the nutritional and metal composition of banana (Musa spp). Journal of Applied Sciences and EnvironmentalManagement, 18(02): 243- 246.

Subbaiah KV, Jagadeesh SJ, Thammaiah N, Chavan ML. 2013. Changes in physico-chemical and sensory characteristics of banana fruit cv. Grand Naine during ripening. Karnataka Journal of Agricultural Sciences, 26(1).

Tapas S. 2016. Effect of post harvest treatments on shelf life and quality of banana cv. Grand Naine. International Journal of Agriculture Sciences.

Tapre AR, Jain RK. 2012. Study of advanced maturity stages of banana. International Journal of Advanced Engineering Research and Studies, 1(3): 272-274.

Zink FW. 1961. Vegetable Deterioration, N6-Benzyladenine, a Senescence Inhibitor for Green Vegetables. Journal of Agricultural and Food Chemistry, 9(4): 304-307. 